Historic, Archive Document

Do not assume content reflects current scientific knowledge, policies, or practices. 

"Gladsome

11

Glads"
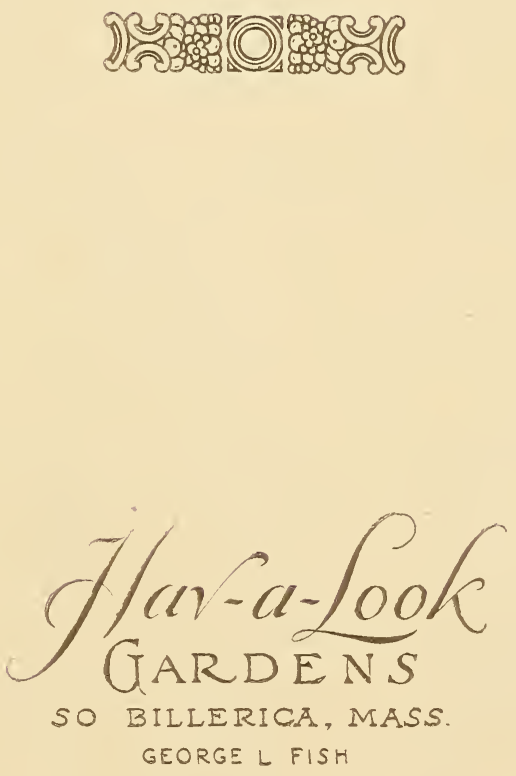

Dalilia Specialist-Gladioli Enthusiast

P O BEOFORO MASS 



\section{THE GLADIOLUS}

$\mathrm{T}$

HE peer of all Summer garden flowers as a cut flower. Easy of culture, with a color range equalled by no other flower grown. The brightest and darkest of reds, purples, blues, mauves, pinks, yellows, though the cream shades to the perfect white, with literally hundreds of distinct varieties from the giant sizes to the smaller hooded primulinus, is it any wonder they are often termed the "Poor Mlan's Orchid". No garden is complete without them.

Hav-a-Look Gardens, has a collection of several hundreds of the choicer varieties. The stock of many of these recent introductions is so limited, however, that we list only such varieties as can be readily supplied and those which can be had at reasonable prices. We shall, however, be more than willing to try and procure for our customers the rarer, scarcer varieties if they will advise us the kinds they desire.

We can supply bulbs of most of the rarieties listed in the different sizes from bulblets to No. 1 bulbs of 1 1-2 inches and upwards. Also by the hundred or thousand as may be desired.

If you can use bulbs in large quantities, write us for special prices.

Bulbs will be shipped via Parcel Post or Express as customer may elect. Buver to pay such charges, excepting single bulbs which will be sent post paid.

Remittances may be made by Registered $\$ lail, P. O. Money Order or American Express Cheques or Bank drafts on Boston, Mass.

Shipments will be filled in the order received and as expeditiously as is possible. An early booking of your order will be appreciated and will facilitate early shipments.

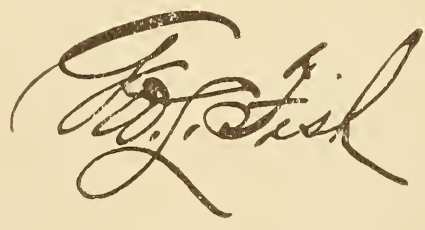




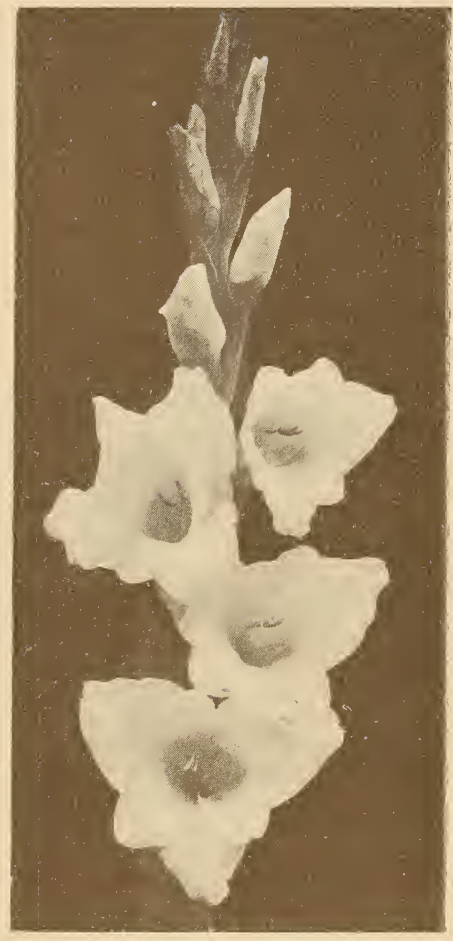

Sreetheart

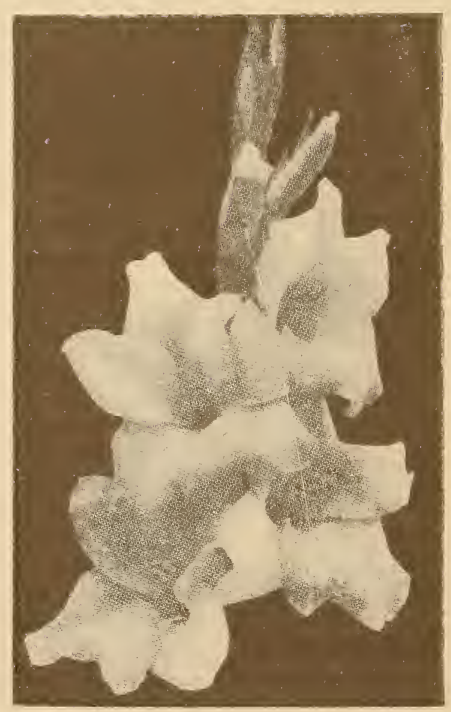

Pink Wondder 


\section{Select List of Newer and Choice Varieties of Proven Merit}

Albania (Kemp). First prize winner. Boston, 1921: New York, 1921-22. Pure glistenirg white wide open flowers, four inches or more in diameter. One of the very finest whites in existence. $30 \mathrm{c}$ each. $\$ 3.00$ dozen.

Anna Eberius (Diener). The sensational plum purple with darker purple throat. One of the most popular glads ever produced.

$25 \mathrm{c}$ each. $\$ 2.50$ dozen.

Byron L. Smith (Kunderd). A refined lavender pink on white ground. Color comparable to a Cattleya orchid
20c each.
$\$ 2.00$ dozen.

Diana. A deep blood red of remarkable clean clear Color. Considered by many judges absolutely the best all round red yet produced.

50c each. $\quad \$ 5.00$ dozen.

Dorothy McKibben (Kunderd). Pure apple blossom pink shades of darker pink. Elegantly ruffled and extra early.

\section{$25 \mathrm{c}$ each. $\$ 2.50$ dozen.}

Elegant Beauty (Kunderd). Large size, beautiful salmon colorings and wonderfully ruffled. One of the very choicest prims.

50c each. $\$ 5.00$ dozen.

Elora (Burbank). A very early creamy white with red throat lines. Very fine. $30 \mathrm{c}$ each. $\$ 3.00$ dozen.

Early S.rowflake (Kemp). First prize Nell York, 1922; first prize, Boston. Silver medal, New York, 1921. Tall. growing twenty or more flowers of largest size, often reaching 0 inches diameter. Color-a rich creamy white, delicately tinted and flaked rose with a tinge of yellow in the throat, very showy, resembling a large lily. A wonderful forcing varicty. $10 \mathrm{c}$ each. $\$ 1.00$ dozen.

Frank J. Symmes (Diener). Salmon rose pink with red center. Ruffled edges, tall spike and large flowers.

$20 \mathrm{c}$ each. $\$ 2.00$ dozen.

Jack London (Diener). Light salmon with brilliant orange flame stripes, golden vellow throat with ruby striped center. Wonderful flower under artificial light.

$25 \mathrm{c}$ each. $\$ 2.50$ dozen.

Jennie Lind (Hoeg). Pure soft apricot pink, throat pale yellow, the two colors perfectly blending. Many blooms open at one time. One of the most exquisite glads in extant.

$50 \mathrm{c}$ each. $\quad \$ 5.00$ dozen

Mary Stephens (Ftsher). White overlaid pink with deep crimson blotch, a charming glad of wonderful texture. Offered for the first time and one of the few glads worth much more than the introductory price.

$\$ 1.00$ each.
Mrs. Frederick C. Peters (Fisher). A wonderful glad. The most delicate shades of lilac rose with crimson blotches on lower petals. Large flowers and many open at one time. Probably the best in the lavender class to date.

$75 \mathrm{c}$ each. $\quad \$ 7.50$ dozen.

Hav-a-Look Blue Belle New. A very choice good size deep blue flower with slight dark maroon throat markings. Now offered for the first time. Stock limited. Not over one dozen to a customer $75 \mathrm{c}$ each. $\$ 7.50$ dozen.

Golden Girl (Meader). A bright yellow primalinas with small dark throat, is very early and makes a fine combination with any of the blue shades. 20 c each. $\$ 2.00$ dozen.

Gold (Hoeg). Pure golden yellow, throat a shade deeper, slightly dotted, and streaked almost a self color. Large flowers, perfectly placed and many open at one time. Considered by many the best yellow grown

40 c each. $\$ 4.00$ dozen.

Golden Measure. One of the best yellows extant. A deep golden yellow of large sized blooms, very tall spikes and a vigorous grower. Vies with gold for best yellow in the opinion of different growers 35 c each. $\$ 3.50$ dozen.

Louise. A fine new lavender of large wide open flowers, wine colored penciling on the lower petals

$25 \mathrm{c}$ each. $\$ 2.50$ dozen

Mallow. White with cinnamon markings in the throat produces a wonderful spike of bloom of grand flowers

$75 \mathrm{c}$ each. $\$ 7.50$ dozen.

Mary Pickford (Kunderd). An extraordinary flower and spike of most delicate creamy white with a throat of sulphur yellow-and exquisite creation and winner of many prizes.

$25 \mathrm{c}$ each. $\$ 2.50$ dozen.

Romance (Kunderd). Large orange, salmon rose with red and yellow throat, wine blue bordered petals. Unusually distinct and very showy.

$35 \mathrm{c}$ each. $\$ 3.50$ dozen.

Rose Glory (Kunderd). A very large beautifully ruffled variety of purest rose pink shading, deeper rose in the throat.

$30 \mathrm{c}$ each. $\$ 3.50$ dozen.

Sweetheart (Kemp). Prim Hybrid:

Prize Winner at Boston, 1921

Color is a light cream, with golden yellow shading on lower petals. Overlaid with faint rose feathering one of the sweetest color combinations imaginable. $25 \mathrm{c}$. each

$\$ 2.50$ per Doz

Violet Beauty (Kunderd). Tall graceful spike of large cerise violet flowers, with a grand red blotched throat distinct and fine $15 \mathrm{c}$ each. $\$ 1.50$ dozen. 


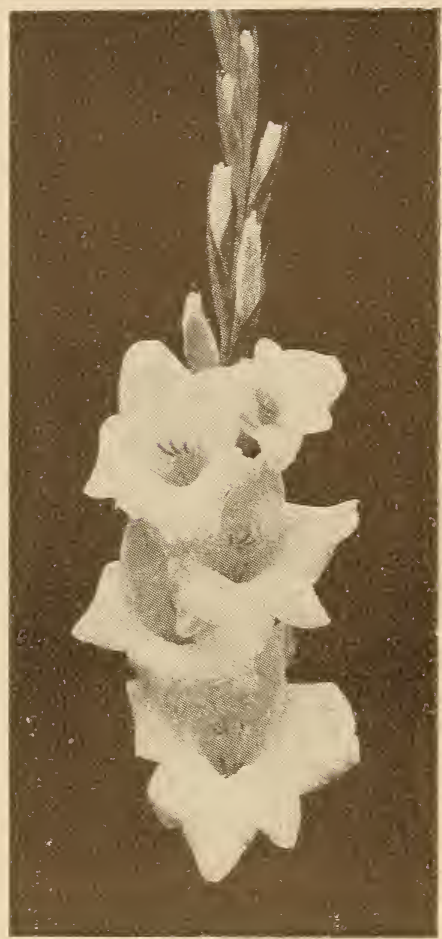

White Wonder

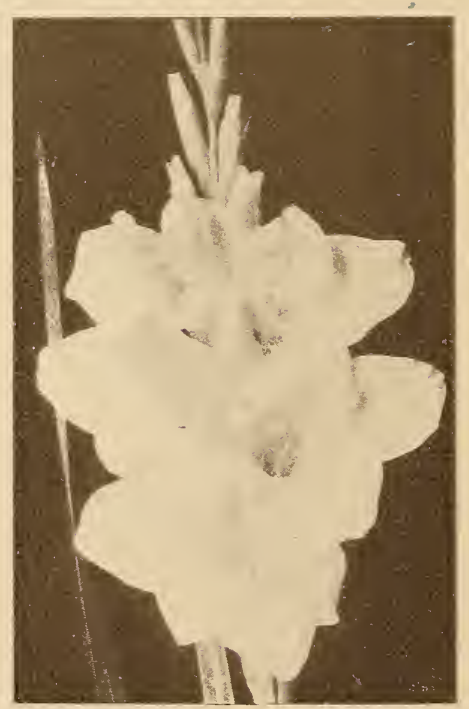

Albania 


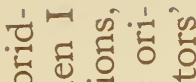

䒕

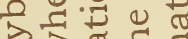

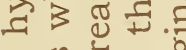

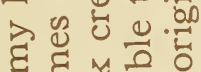

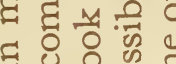

a 0 웅

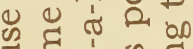

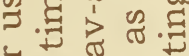

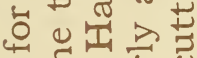

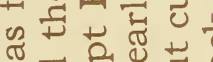

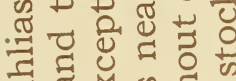

和苂设

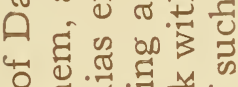

के

范

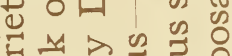

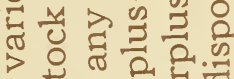

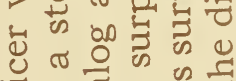

0

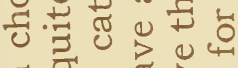

$\checkmark$ o 0

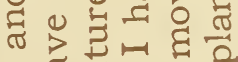

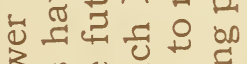

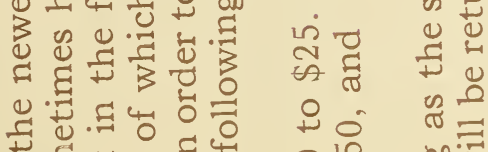

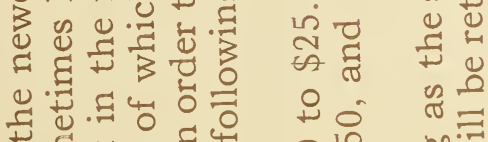

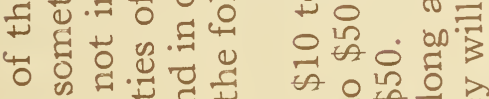

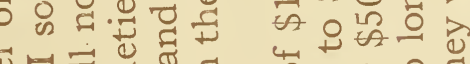

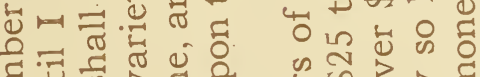

है

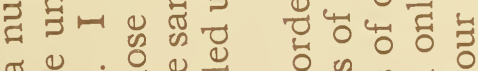

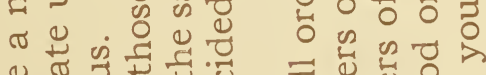

\%

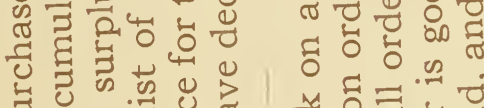

苍.

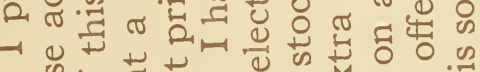

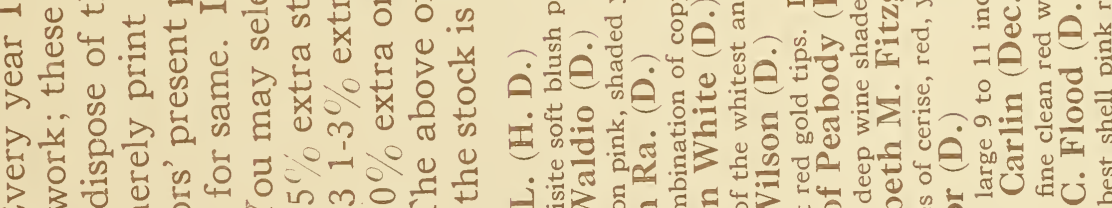

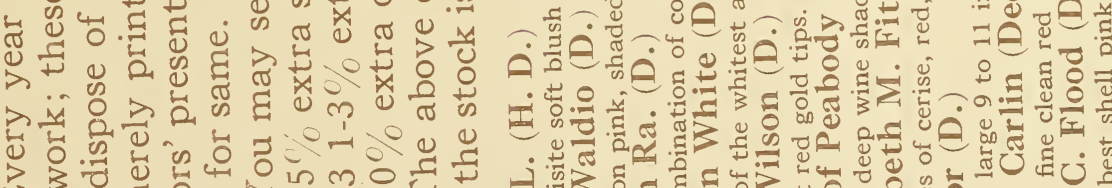

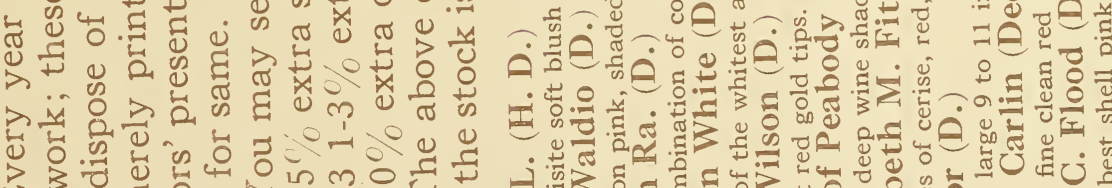
구의

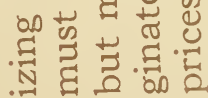
等

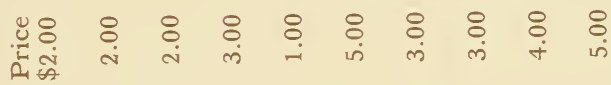

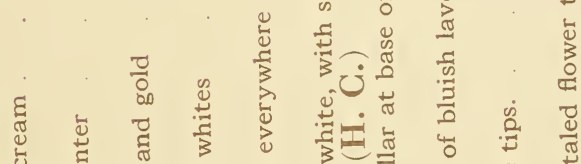

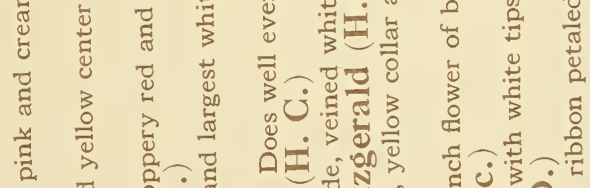
8 - 8 -

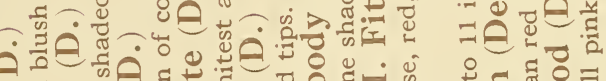

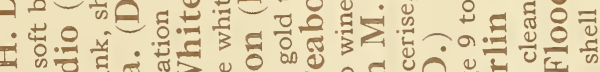

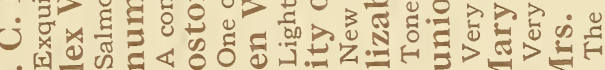

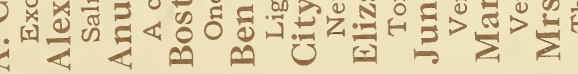



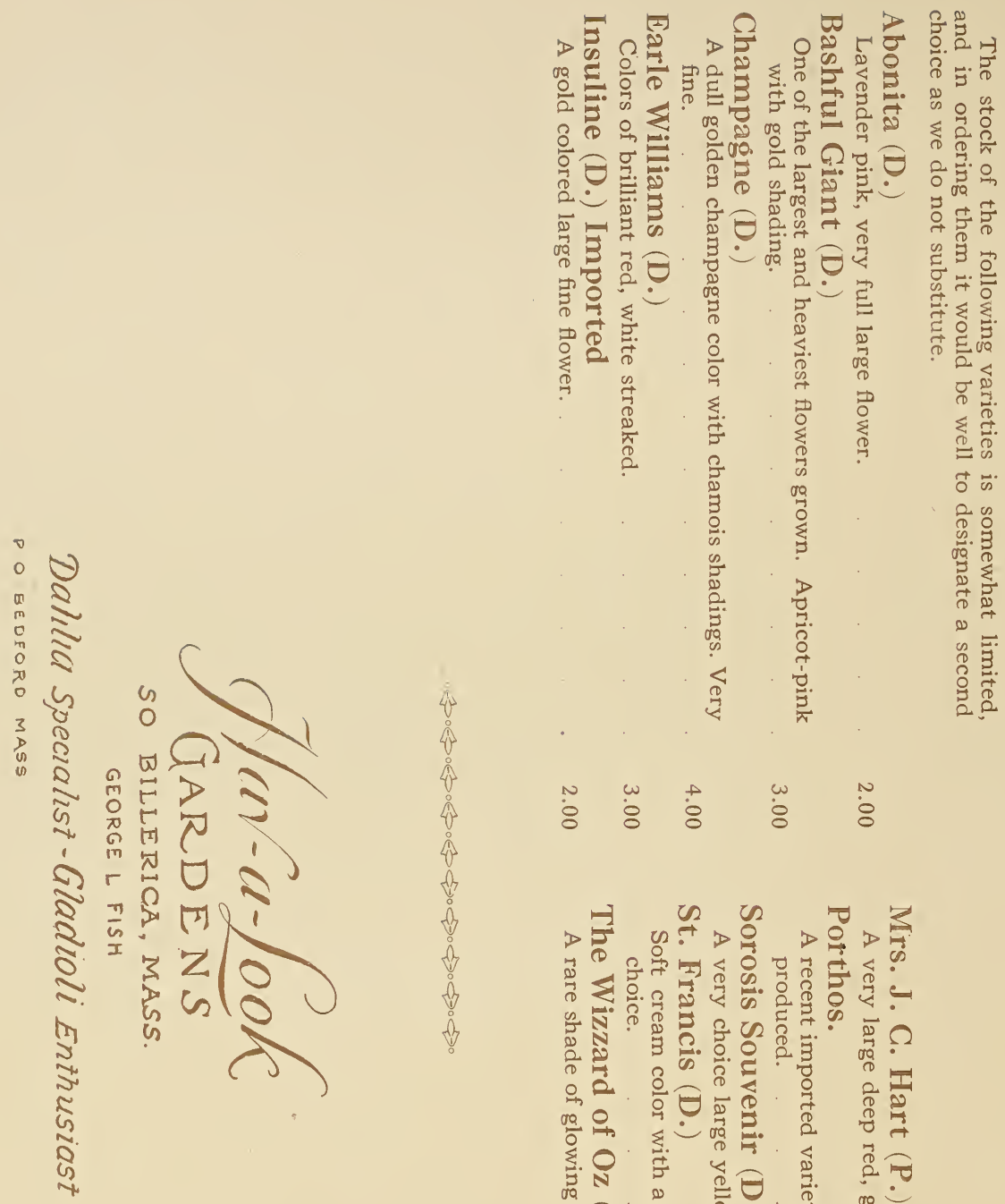

$\begin{array}{lllll}N & \omega & + & \omega & N \\ \delta & 8 & 8 & 8 & 8\end{array}$

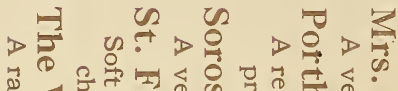

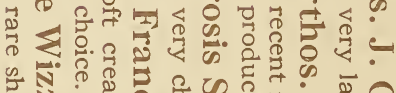

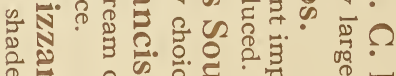

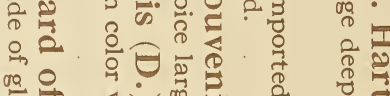

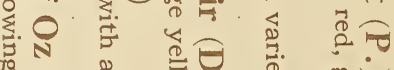

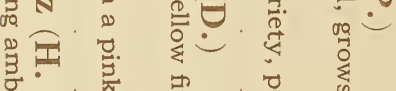

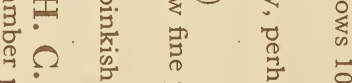

ช. $\begin{array}{ccc}0 \\ 0\end{array}$

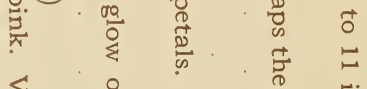

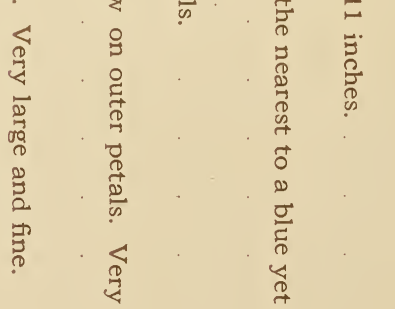

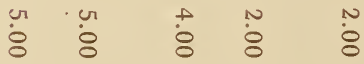


Peach Rose (Kunderd). An extra choice distinct deep rose pink with darker throat One of the most striking colored glads grown. Stock is very scarce

60 c each. $\$ 6.00$ dozen.

Pink Wonder (Kemp) Truly the most wonderful pink "Glad" yet produced, strong. vigorous grower. 17 to 19 blooms, and 4 and 5 massive flowers open at one time, many of them $6 \frac{1}{2}$ inches in diameter. The color is soft La France pink flaked Geranium pink, with chartreuse vellow in the throat, overlaid with Rose feathering

25 c each. $\$ 2.50$ dozen.

Snowdrift (New). A pure white sport of America, with the same shape and texture. A strong grower and a prize winner. One of the very best exhibition whites.

50c each. $\$ 5.00$ dozen.
Sweet Brier ( $N e w$ ). Shell pink with a deeper pink stippling in the throat, an exquisite variety 50 c each. $\$ 5.00$ dozen

Par Excel (Kunderd). Of purest deep salmon pink with finest large Pelargonium throat blotches. very striking variety

$20 \mathrm{c}$ each. $\$ 2.00$ dozen.

White Wondar (Kemp). A descendant of the popular variety: Mrs. Francis King, and endowed by all of King's fine quality, except color. which is pure white without any throat markings. Very large fowers up to $53-4$ inches in diameter well placed. and 4 to 5 open at one time. One of the grandest whites and a prize winner.

25 c euch. $\$ 2.50$ dozen.

Willis E. Fryer (Kunderd). Very large massive deep violet with a beautiful throat coloring. Extra fine

50c each. $\$ 5.00$ dozen.

\section{Named V'arieties of Supreme Quality}

Alice Tiplady. Primulinus hybrid. Extra large orange saffron flower of the honded type. Very choice

$15 \mathrm{c}$ each. $\$ 1.50$ dozen.

Baron Hulot. Deep violet blue, the hest dark bluc in cultivation. Always attracts attention. 10 c each. $\$ 1.00$ dozen.

Blue Jay. The finest American hlue gladiolus. Flowers bright blue with pure white spots in throat. "True Stock."

$35 \mathrm{c}$ each. $\$ 3.50$ dozen.

Crimson Glow. Perfect deep scarle. ()pen flowers of largest size and well placed.

$20 \mathrm{c}$ each. $\$ 2.00$ dozen.

E. J. Shaylor. Beautifully ruffled, of deepest rosepink. Pure rose

20 c each. $\$ 2.00$ dozen.

Evelyn Kirtland. Beautiful shade of rosy pink soft shell-pink center, bright scarlet hlotches on lower petals. A prize winner everywhere. 15 c each $\$ 1.50$ dozen.

Flora. Canary yellow; with scarcely any markings Flowers well placed, plant tall and itrong. One of the very best yellows in existence.

\section{0c each. \$2.00 dozen.}

Gen. Pershing. New. Very large. Upperpetal-pale pink Lower petals yellow, striped rich carmine. 25c each. \$2.50 dozen.

Gretchen Zang. Lovely melting salmon-pink very beautiful.

10 c each. $\$ 1.00$ dozen.

Herada. Clear brilliant mauve; blossoms of immense size, a wonderful new culor. $10 \mathrm{c}$ each. \$.50 dozen.

Le Marechal Foch. Beautiful shade of light pink. Enormous wide open flowers Very carly and a good grower? One of the latest inmortations from Holland, and very highly recommended.

10c each. \$1.00 dozen.
Lilywhite. Unyuestionably the best early white grower. As early as Hally. Ideal for forcing. and a sure bloomer even from very small bulbs. As a florist's white it cannot be surpassed.

Strong bulbs, 10c each. $\$ 1.00$ dozen. $\$ 6.00$ er 100

Mary Fennell. Palest lavender, tinged soft ink. paler throat Large wide open Hower s of misty loveliness. A Patrician among gladioli. $20 \mathrm{c}$ each. $\$ 2.00$ dozen.

Mrs. Dr. Norton. Solt La France pink with creamy-throat large open flowers, tall spikes and a rrize winner everywhere. Nothing better A warded Silver Medals by Mass. Horticultural Society:

Fine bulbs, 20c each. 2.00 dozen.

Mrs. Francis King. Enormous flowers of beautiful ame-pink

$\mathbf{5 c}$ each. 50c dozen.

Mrs. Frank Pendleton. Bright rose-pink on a pure white ground. A giant blotch of richest varmine red on lower petals 10 c each. $\$ 1.00$ dozen.

Mrs. G. W. Moulton. Flowers of extra large size: a solid dark rose re 1 in color with very slight tracings of deeper color in throat. Very showy

20 e euc'. $\$ 2.00$ dozen.

Mrs. Watt. Roval red rose color, an American beauty shade, clear solid crimson I variety that everyone loves at first sight.

1Cc euch. $\$ 1.00$ dozen.

Myrtle. Tender and delicate rose pink, in the lovely shades of the trailing arhutus. The most beautiful pink yet produced in a gladiolus.

15c euch. $\$ 1.50$ dozen.

Niagara. Very large, open flowers of soft, pale yellow:

10c each. \$1.00 dozen. 
Panama. Deeper pink than America, of which it is a seedling. A lovely soft color, and considered by many the very best pink sort.

$10 \mathrm{c}$ each. $\$ 1.00$ dozen.

Peace. Giant blooming white, very strong grower. strong lilac mark in throat. Flowers of great size and beaut :

$10 \mathrm{c}$ each. $\$ 1.00$ dozen

Prince of Wales. Lovely soft salmon of largest size. Very early

10 c each. $\$ 1.00$ dozen.
Rouge Torch. Large creamy-white flower with a rouge torch-like tongue on inferior petals, making a very striking contrast. $10 \mathrm{c}$ each. $\$ 1.00$ dozen.

Schwaben. Canary yellow, shading to soft sulphury yellow.

10 c each. $\$ 1.00$ dozen.

Wilbrink. Like Halley only of sott pink, very early:

$10 \mathrm{c}$ each. $\$ 1.00$ dozen.

\section{TWO NEW PRIMS \\ (Of exceptional merit that are very early)}

Maidens Blush ( New). The finest pink prim soft apple blossom pink, delicate, dainty, and appropriately named.
15 each
$\$ 1.50$ dozen.
$\$ 10.00$ per 100

Souvenir (New). Unquestionably the best deep yellow prim to date. No collection complete without it.

$15 \mathrm{c}$ eajh. \$1.50 dozen. $\$ 10.00$ be- [17]

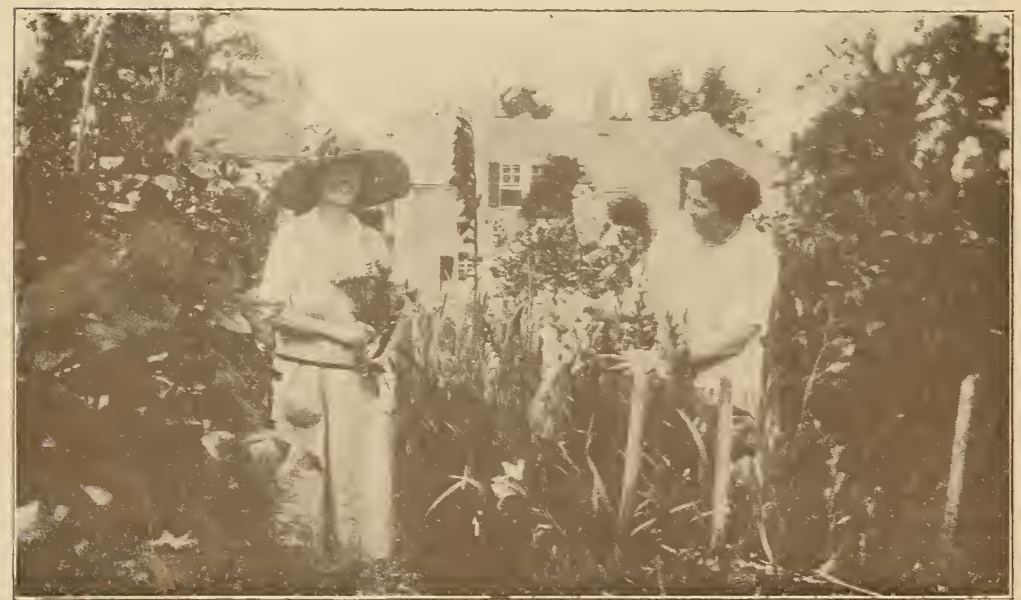

In the Garden of Gladiola 